\title{
Scrutinizing Domestic Garbage Disposal Techniques of Slum Dwellers: A Study on Slum Areas of Sylhet City of Bangladesh
}

\author{
Mufti Nadimul Quamar Ahmed", Golam Moula, Sayed Bokth Mojumadar \\ Department of Sociology, Shahjalal University of Science and Technology (SUST)
}

*Corresponding Author: Mufti Nadimul Quamar Ahmed, Department of Sociology, Shahjalal University of Science and Technology (SUST)

\begin{abstract}
Major purpose of this study was to investigate the domestic waste disposal techniques of slum dwellers. This study also tried to assess their surrounding environmental condition. To conduct the study, two slum areas; Ranu's colony and Helal Miah's colony, were selected as study areas. Both of the locations fall under ward no. 8 governed by Sylhet City Corporation (SCC). In total, 50 households head participated in the household survey administered through structured questionnaire. The descriptive design incorporated mean, standard deviation, table and bar graph utilizing SPSS for data analysis and presentation. The study indicates most of the slum residents throw their domestic wastes into nearby yards. Furthermore, the study reveals variations of the slum-dwellers in terms of education, income, age and so on. The most fascinating distinction yields in their perception towards waste management responsibility. Nearly $65 \%$ respondent of Helal Miah`s colony reveals that slum-owners should take this responsibility, while $42.4 \%$ respondent in Ranu's colony reveals slum-dwellers should be responsible for this. However, a significant number of them, $78.8 \%$ of Helal Miah's colony and 47\% of Ranu's colony, strongly agrees that throwing waste everywhere is deleterious to environment. It is recommended from this study that the local governments; city corporation or municipality, in conjunction with NGO's should devise an organized plan to make slum dwellers aware about potential risks associated with poorly disposed waste. Further study may include the interaction between poor waste management and its impact over the immediate environment.
\end{abstract}

Keywords: Domestic Garbage, Colony, Slum dwellers, SCC.

\section{INTRODUCTION}

Due to the disproportionate increase in income opportunities, the accelerated population in Bangladesh encounters problems of poverty long since. Consequently, a considerable number of people lives below the poverty line. Among them, rural inhabitants appear to be more vulnerable who, in most cases, are denied to learn skills that could usher in income opportunities for them. To overturn their fortune, they tend to migrate into the urban areas; nearby or far, where they are forced to live in the slum areas. Generally, a slum is seen as an unhealthy area where basic amenities like water supply, drainage for a standard living are lacking. Increasing magnitude of immigration incapacitates the urban governing body to satisfy housing demands of urban-dwellers which give birth to the emergence of such informal settlements. Furthermore, the city authority attempts to properly manage the domestic wastes produced by these concentrated settlements where inhabitants tend to carelessly dispose of wastes in absence of authority. The poor management of waste often leads to the environmental and health hazards. The slum-dwellers appear to be more susceptible to various waterborne diseases such as typhoid, diarrhea, hepatitis and so on. According to Sankoh et al. (2013), waste in slum area is ultimately thrown into municipal disposal sites and due to poor and effective management, the dumpsites turn to sources of environmental and health hazards to people living in the vicinity of such dumps. Especially, the cities in developing countries seem more vulnerable to severe health and environmental consequences in terms of unplanned waste management. The UNEPA (2006) states that wastes that are not properly managed, especially excreta and other liquids and solid wastes from households and the community, are a serious health hazard and could lead to the spreading of diseases. Underscoring the implication of poorly managed wastes, this paper attempts 
to assess the disposal of domestic wastes produced by the slum-dwellers and the frequency of diseases in those areas. Moreover, this paper seeks to observe the condition of surrounding environment of the studied slum areas.

\section{RELEVANT LITERATURES}

Tinni, S.H., et al. (2014) administered a survey on the sample of 300 in Dhaka to unwrap the awareness of the environmental impacts that follow the tannery waste disposal. The sample incorporates day laborers (90), livestock farmers (60), fisherman (60) and local inhabitants (90). The questionnaire includes respondent's age, education level, occupation, type of wastes, color of wastes, their waste disposal time and environmental effect. The findings reveal that 34 percent respondents were illiterate. $56 \%$ of both solid and liquid waste was come out from the tannery and half of them were black in color. The findings also signify that respondents were facing different health problems such as skin diseases, itch, rash, cough, fever, diarrhoea, headache, asthma, dizziness etc. Furthermore, the study discovers the proportional relationship of degree of awareness with the years of schooling. The researchers also found significant positive relationships between education, occupation, type of wastes and respondents environmental pollution awareness.

Abul, S. (2010) conducted a study on the effects of the dumpsite on the surrounding human settlements in which he collected data from 78 household heads using a self-administered questionnaire. The study area incorporated the Mangwaneni area adjacent to Golf Course dumpsite in the city of Swaziland. In addition, the study attempts to figure out the possible health and environmental consequences preceded by the waste disposal in the vicinity of their homes. To satisfy his objectives, the author conducted comparison the impacts on the inhabitants in terms of distance of their respective homes; nearby and far away. The findings suggest that both respondents experience health consequences. The residents whose houses are less than 200 meters from the dumpsite are the victims of malaria, chest pains, cholera, and diarrhoea. On the other hand, residents whose houses are more than 200 meters away are also affected with the chest pain and bad smell from the dumpsite, but mainly when wind is blowing at their direction. Therefore, he recommended that dumpsites should be properly located and managed to minimize its effects on the environment as well as government and municipalities should revise laws regarding the locations of the dumpsites.

Islam, S. F.A., \& Islam, M. (2016) conducted a study on sanitation and waste management problem on the sample of 100. The data were collected from the slum dwellers living in Uttara, Dhaka through a self-administered questionnaire. Their study finds that there is no fixed place for waste disposal. Generally, wastes are disposed on the nearby ground or above the water body. Approximately $25 \%$ dispose wastes into the water body, while $73 \%$ of households dispose on the ground, mainly on the street. Though only $2 \%$ of households have been found to dispose wastes in dustbin. Moreover, They observed that the sanitation situation was worst against the current water supply in the Uttara`s Slum area. The result obtained about mode of defecation for pit latrine, septic tank system and water seal latrine were $65 \%, 27 \%$ and $08 \%$, respectively, in the studied area where majority of the people (72\%) of the slum areas does not use soap after defecation.

Zurbrugg, C. (2002) conducted a study in the least developed countries (LDCs) in Asia including Bangladesh on urban solid waste management in which he revealed that rapid and unplanned urbanization exacerbated the process of solid waste management. Many a times, around one to twothirds of wastes remained uncollected which in turn spread over streets and drains mixing with human and animal excreta. As a result, floods, breeding of insects, rodent vectors and spread of various water-borne diseases appear to be regular phenomenon in those areas. The author concluded that the urban solid waste in low-income Asian countries which is collected is dumped on land in a more or less uncontrolled manner. Such inadequate waste disposal creates serious environmental problems that affect health of humans and animals and cause serious economic and other welfare losses.

Sankoh, F.P., Yan, X., \& Tran, Q. (2013) administered a study on the environmental and health impacts of solid waste disposal on the sample of 631 using self-administered questionnaire. Among the respondents, 398 resides less than 50 metres away from nearby dumpsite household residents $(<50$ 
metres) while 233 resides more than 50 metres away ( $>50$ metres). The study location incorporates the municipal areas of the Sierra Leone`s capital, Freetown. Their study shows that both nearby and far away residents suffer from diseases such as malaria, chest pains, diarrhea and cholera.

\section{MeTHOdOLOGY}

Sylhet Municipality was established in 1878 with an area of $10.49 \mathrm{sq} \mathrm{km}$ with 5 wards. It was transformed into a city corporation in 2001 and currently, the city is governed by the Sylhet City Corporation (SCC). As of 2011, Sylhet City Corporation occupies a total area of $26.5 \mathrm{sq} \mathrm{km}$. It has 27 wards and 207 Areas known as Mahallahs. Ward No. 8 of Sylhet City Corporation is divided into 8 areas. These are known as Brahman Shashan, Hauldar Para, Kucharpara, Korarpar, Noapara, Panitala, Pathantala, Uttar Pir Mahalla. This research is conducted in Hauldar Para and Korarpar area under 8 No. ward of Sylhet City Corporation. Among many colonies "Ranu's colony" and "Helal Miah's colony"' were selected from Hauldar Para and Korarpar area respectively. Study areas were selected purposively. Maps of Sylhet City Corporation highlighting the study area is presented in figure 1 .

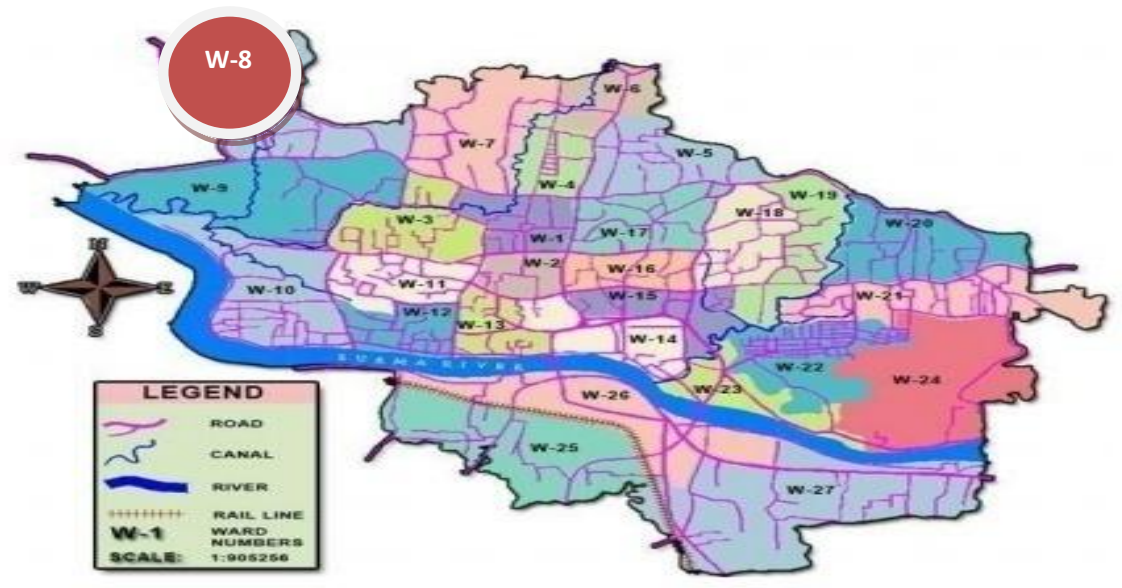

Figure1. Map of Administrative Wards of Sylhet City Corporation (SCC) Highlighting the Respective Ward of Study Areas

Source: www.sylhetcitycorporation.gov.bd

All the households of "Ranu's colony" and "Helal Miah's colony" are the population of this study. There are 33 households belonging to Ranu's colony and total number of households belonging to Helal Miah's colony is 17 . Therefore, population size of this present study is $33+17=50$. Keeping the aims of this study in mind, data have been collected from the household head of each household. As our population size is small therefore we consider our population as samples of this study. Therefore, household head from each household were the respondent of this study. If the male household head was absent during data collection time then we collect data from the female head of that household. Descriptive research design has been followed throughout the research which is most commonly used in social research to describe situations and events through studies (Babbie, 2004, p. 89; Islam, 2011, p. 87). Household survey was the main method to collect quantitative data in this research. Household head was interviewed about their demographic and socio-economic condition, their garbage disposing techniques as well as about their surrounding environment where they live. In case of survey, a standard questionnaire was provided to the respondents for collecting data where maximum questions were close ended form. Some questions were remaining open ended for knowing respondents view on that particular topic. Data have been analyzed in accordance with the objectives of this study. These analyses have been done in quantitatively. The quantitative data have been analyzed by using different statistical tools and techniques such as mean, standard deviation, percentage etc. These outputs are presented in this paper with the expression of different tables, box, bar graph etc. SPSS (Statistical Package for Social Sciences) version 16 was used to analyze the quantitative data. 


\section{FINDINGS}

\subsection{Socio-Demographic Characteristics of the Respondents}

Table1. Socio-demographic characteristics of the respondents

\begin{tabular}{|c|c|c|}
\hline \multirow{2}{*}{ CHARACTERISTICS } & Ranu's Colony & Helal Miah's Colony \\
\cline { 2 - 3 } Gender & $\%(\mathbf{n})$ & $47.0(8)$ \\
Male & $42.4(14)$ & $53.0(9)$ \\
Female & $57.6(19)$ & $65(11)$ \\
\hline Religion & & $35(6)$ \\
Muslim & $13(4)$ & $59(10)$ \\
Hindu & $87(29)$ & $18(3)$ \\
\hline Age Group & & $23(4)$ \\
Young Age (18-36) & $33(11)$ & $41.2(7)$ \\
Middle Age (37-55) & $46(15)$ & $58.8(10)$ \\
Elderly (56+) & $21(7)$ & $0.0(0)$ \\
\hline Education & $36.4(12)$ & $35.3(6)$ \\
No Years of Schooling & $45.5(15)$ & $52.9(9)$ \\
1-5 Years & $18.1(6)$ & $11.8(2)$ \\
\hline 6-10 Years & & \\
\hline Family Size & $48.5(16)$ & $(15)$ \\
Small (2-4) & $6.0(2)$ & \\
Medium (5-6) & & \\
Large (6+) & & \\
\hline
\end{tabular}

The table 1 suggests that out of the total respondents from Ranu's colony, 42.4\% were male and $57.6 \%$ were female. On the other hand, among the respondents from Helal Miah's colony $47 \%$ were male and $53 \%$ were female. Both of the colonies have more female members comprising 28 as compared to only 22 male members. According to the findings, Hindus seem superfluous against Muslim's inhabiting in both colonies. 87\% respondents in Ranu's colony are Hindu which is $65 \%$ in Helal Miah's colony. The table above indicates that young-aged respondents comprises majority $(59 \%)$ in Helal Miah's colony which is 33\% in Ranu's colony. Being the minority in the Helal Miah's colony, the middle aged group appears majority (46\%) in the Ranu's colony. 21 respondent from Ranu's colony and 23\% from Helal Miah's colony are belonging to old age group. The table above signifies that majority of the respondents comprising both colonies have received primary education, while 36.4\% percent and 41.2\% from Ranu's colony and Helal Miah's colony respectively have no formal education at all. Surprisingly, only 18.1 percent respondents have received secondary education of which none of them belongs to Helal Miah's colony. The table above also shows that medium size family (52.9 percent) seems more dominant in Helal Miah's colony while small family size comprising $48.5 \%$ is dominant in Ranu's colony. Narrow percentage of respondents yields large family size consisting of more than 6 members in both the studied colonies.

\subsection{Garbage Disposal Systems in Both Colonies}

The below table 2 signifies that more than half of the respondents in both colonies disposes their home-grown wastes in the yards; $51.5 \%$ of Ranu's colony and $52.9 \%$ of Helal Miah`s colony. On the other hand, nearly $40 \%$ of the former disposes wastes into dustbin as compared to $35.3 \%$ in the latter while around $10 \%$ of them throw into canals and other places. Furthermore, Mostly female members of both colonies; $72.7 \%$ of Ranu's colony and $82.4 \%$ of Helal Miah's colony, dispose wastes against their male counterpart $21.2 \%$ of the former and $17.6 \%$ of the latter. Between the studied colonies, only the kids of the former shoulder this responsibility in a narrow number. Furthermore, Most of the respondent's yields they possess locally built disposal facilities while they claim to have seen municipality attempts to collect wastes through van and built-in facilities. Most of them observe such attempt on daily basis. Only $17.6 \%$ of the Helal Miah's colony observes attempts once in a week as compared to $9.1 \%$ in the other. The rest of them confirms to have seen twice and once in a month. As for toilet, most of the inhabitants enjoy partly-brick build made toilet while less than $20 \%$ enjoys mud-built toilet facilities in the both settings. Surprisingly, Ranu's colony (27.3\%) posses more brickbuilt made facilities than the Helal Miah`s (5.9\%) colony. However, roughly $12 \%$ of the former and $3 \%$ of the latter posses roofless facilities. Interestingly enough, both of the colonies shows contrasting 
perceptions regarding the bearing of waste management responsibility. Ranu`s colony (42.4\%) seems more aligned to slum dwellers while most inhabitants (64.7\%) of the Helal Miah`s colony claims that slum-owners should have to bear this responsibility. Nearly 20 percent of both colonies indicate family members whereas rest of them points on municipality.

Table2. Garbage disposal systems in both localities

\begin{tabular}{|c|c|c|}
\hline Items & Ranu's Colony $\%$ (n) & $\begin{array}{l}\text { Helal Miah's Colony } \\
\% \text { (n) }\end{array}$ \\
\hline $\begin{array}{l}\text { Where do dispose home-grown wastes } \\
\text { 1. Dustbin } \\
\text { 2. Yard } \\
\text { 3. Canal } \\
\text { 4. Others }\end{array}$ & $\begin{array}{l}39.4(13) \\
51.5(17) \\
6.1(2) \\
3.0(1)\end{array}$ & $\begin{array}{r}35.3(6) \\
52.9(9) \\
5.9(1) \\
5.9(1)\end{array}$ \\
\hline $\begin{array}{l}\text { Responsible member in the family for waste } \\
\text { disposal } \\
\text { 1. Male members } \\
\text { 2. Female members } \\
\text { 3. Children }\end{array}$ & $\begin{array}{c}21.2(7) \\
72.7(24) \\
6.1(2)\end{array}$ & $\begin{array}{c}17.6(3) \\
82.4(14) \\
0.0(0)\end{array}$ \\
\hline $\begin{array}{l}\text { Do they have a locally built place for waste } \\
\text { disposal } \\
\text { 1. Yes } \\
\text { 2. No }\end{array}$ & $\begin{array}{l}69.7(23) \\
30.3(10)\end{array}$ & $\begin{array}{c}88.2(15) \\
11.8(2)\end{array}$ \\
\hline $\begin{array}{l}\text { Does the locality ever witness any municipality } \\
\text { attempt to manage waste } \\
\text { 1. Yes } \\
\text { 2. No }\end{array}$ & $\begin{array}{l}87.9(29) \\
12.1(4) \\
\end{array}$ & $\begin{array}{l}94.1(16) \\
5.9(1)\end{array}$ \\
\hline $\begin{array}{l}\text { (If yes) How do they manage } \\
\text { 1. Van } \\
\text { 2. Built in facility }\end{array}$ & $\begin{array}{l}75.8(25) \\
12.1(4) \\
\end{array}$ & $\begin{array}{l}70.6(12) \\
23.5(4) \\
\end{array}$ \\
\hline $\begin{array}{l}\text { Interval do they follow to manage waste } \\
\text { 1. Daily } \\
\text { 2. Once in a week } \\
\text { 3. Once in } 15 \text { days } \\
\text { 4. Once in a month }\end{array}$ & $\begin{array}{l}60.7(20) \\
9.1(3) \\
3.0(1) \\
3.0(1)\end{array}$ & $\begin{array}{l}70.6(12) \\
17.6(3) \\
5.9(1) \\
0.0(0)\end{array}$ \\
\hline $\begin{array}{l}\text { Type of toilet family members do use } \\
\text { 1. Roofless } \\
\text { 2. Mudbuilt } \\
\text { 3. Partly brick built } \\
\text { 4. Brick built }\end{array}$ & $\begin{array}{l}3.0(1) \\
18.2(6) \\
51.5(17) \\
27.3(9)\end{array}$ & $\begin{array}{c}11.8(2) \\
17.6(3) \\
64.7(11) \\
5.9(1)\end{array}$ \\
\hline $\begin{array}{l}\text { Who should bear waste management responsibility } \\
\text { 1. Family members } \\
\text { 2. Slum-dwellers } \\
\text { 3. Municipality } \\
\text { 4. Slum-owners }\end{array}$ & $\begin{array}{l}18.2(6) \\
42.4(14) \\
12.1(4) \\
27.3(9)\end{array}$ & $\begin{array}{c}23.5(4) \\
5.9(1) \\
5.9(1) \\
64.7(11)\end{array}$ \\
\hline
\end{tabular}

\subsection{Surrounding Environment of Both Localities}

The table 3 indicates that 33 families get access to only 4 toilets in the Ranu`s colony and the Helal Miah`s colony provides only 3 toilets for 17 families home into the colony. As for water, all of the residents in both colonies collect water from the local tube wells for domestic and drinking purposes. Only $11.8 \%$ of residents of Helal Miah`s colony use water purification technique for getting safe drinking water while no one in the Ranu`s colony use it. Furthermore, a narrow portion (12\%) of both the colonies involves in rearing livestock's. The studied colonies experience mosquito bites very frequently in a considerable percentages; $54.5 \%$ and $70.6 \%$ for Ranu`s colony and Helal Miah`s colony respectively. Contrarily, only a slight portion (12\%) has never experienced such bites. Regarding diseases, Diarrhoea has been found to be the dominant in both colonies. More than half inhabitants of The Helal Miah`s colony suffers from the Diarrhoea as compared to 33\% in the Ranu`s colony. Merely $12 \%$ of the later survives from dengue and other kinds of disease against no one in the former. Apart from these, the table above indicates slightly more people experience Malaria, Typhoid, Jaundice and skin diseases in the Helal Miah`s colony. Further, exactly $78.8 \%$ of Ranu`s colony 
strongly agrees with the fact that throwing waste everywhere is deleterious to environment as against $47.1 \%$ in the Helal Miah`s colony while $21.2 \%$ of the former agrees with it against $52.9 \%$ of the later.

Table3. Surrounding Environment of both localities

\begin{tabular}{|c|c|c|}
\hline Items & Ranu's Colony \% (n) & Helal Miah's Colony \% (n) \\
\hline $\begin{array}{l}\text { Involvement in any livestock rearing } \\
\text { 1. Yes } \\
\text { 2. No }\end{array}$ & $\begin{array}{c}6.1(2) \\
93.9(31)\end{array}$ & $\begin{array}{c}5.9(1) \\
94.1(16)\end{array}$ \\
\hline $\begin{array}{l}\text { Source of water in household for domestic purpose } \\
\text { 1. Tubewell } \\
\text { 2. Canal } \\
\text { 3. Municipality }\end{array}$ & $\begin{array}{l}100(33) \\
0.00(0) \\
0.00(0)\end{array}$ & $\begin{array}{l}100(17) \\
0.00(0) \\
0.00(0)\end{array}$ \\
\hline $\begin{array}{l}\text { Source of drinking water in your household } \\
\text { 1. Tubewell } \\
\text { 2. Canal } \\
\text { 3. Municipality }\end{array}$ & $\begin{array}{l}100(33) \\
0.00(0) \\
0.00(0)\end{array}$ & $\begin{array}{l}100(17) \\
0.00(0) \\
0.00(0)\end{array}$ \\
\hline $\begin{array}{l}\text { Using any water purification method in your } \\
\text { household } \\
\text { 1. Yes } \\
\text { 2. No }\end{array}$ & $\begin{array}{l}0.00(0) \\
100(33)\end{array}$ & $\begin{array}{c}11.8(2) \\
88.2(15)\end{array}$ \\
\hline Number of families do inhabitant at the locality & $33(\mathrm{n})$ & $17(\mathrm{n})$ \\
\hline Number of toilets are in the locality & $4(n)$ & $3(n)$ \\
\hline $\begin{array}{l}\text { How frequently the localities encounter mosquito } \\
\text { bites } \\
\text { 1. Very frequently } \\
\text { 2. Frequently } \\
\text { 3. Very rarely } \\
\text { 4. Not at all }\end{array}$ & $\begin{array}{l}54.5(18) \\
24.2(8) \\
15.2(5) \\
6.1(2)\end{array}$ & $\begin{array}{l}70.6(12) \\
17.6(3) \\
5.9(1) \\
5.9(1)\end{array}$ \\
\hline $\begin{array}{l}\text { Kind of diseases are more noticeable in the locality } \\
\text { 1. Malaria } \\
\text { 2. Typhoid } \\
\text { 3. Diarrhoea } \\
\text { 4. Jaundice } \\
\text { 5. Dengue } \\
\text { 6. Skin-disease } \\
\text { 7. Others }\end{array}$ & $\begin{array}{c}12.1(4) \\
18.2(6) \\
33.1(11) \\
5.1(2) \\
3.0(1) \\
18.2(6) \\
9.1(3)\end{array}$ & $\begin{array}{l}17.6(3) \\
11.8(2) \\
52.9(9) \\
5.9(1) \\
0.0(0) \\
11.8(2) \\
0.0(0)\end{array}$ \\
\hline $\begin{array}{l}\text { Throwing wastes everywhere is deleterious to the } \\
\text { environment } \\
\text { 1. Strongly Agree } \\
\text { 2. Agree } \\
\text { 3. No comments } \\
\text { 4. Disagree } \\
\text { 5. Strongly Disagree }\end{array}$ & $\begin{array}{l}78.8(26) \\
21.2(7) \\
0.00(0) \\
0.00(0) \\
0.00(0)\end{array}$ & $\begin{array}{l}47.1(8) \\
52.9(9) \\
0.00(0) \\
0.00(0) \\
0.00(0)\end{array}$ \\
\hline
\end{tabular}

\section{DiSCUSSIONS}

The current study compares the two studied colonies where the respondents differ in terms of family size, age, education and income in varying degrees. Slightly less than half of the respondents belongs to small-sized family in Ranu's colony whereas, more than half of the respondents possesses mediumsized family in Helal Miah's colony. As for age, middle-aged group figures more in the Ranu's colony as compared to young-aged Helal Miah`s colony. Furthermore, the study reveals narrow mean differences between the two studied colonies as to education level. Surprisingly, no one in the latter recieves secondary education while the former possesses highest $10^{\text {th }}$ graders. However, the illiteracy rate appears $36.4 \%$ in Ranu's colony which is $41.2 \%$ in Helal Miah's colony. Regarding income, $10 \%$ of the former earns more than 7500 per month while, on the other hand no one earns such in the latter. Both colonies show varying attitudes toward the bearing responsibility of waste disposal and throwing waste anywhere. As for Ranu's colony, the respondents mostly thinks that slum-dwellers should have to bear this responsibility; contrarily, slum-owners are responsible for waste disposal as per the most respondents of Helal's colony. Even though, having comparably more educated individuals, Ranu`s colony involves kids in the waste disposal activities. On top of that, nearly 80 percent of the colony 
members strongly agree with the fact that throwing waste everywhere is deleterious for environment against $47.1 \%$ in the Helal Miah's colony. The current study employs mostly close-ended and slightly open-ended question which suggests both of the colonies rarely differs in some respect as to the disposal of garbage. According to the close ended question findings, more than half of the colonies dispose their wastes into their respective yards, while findings of open ended question suggest that they dispose on the roadside for the municipalities' van to collect. Findings of this study suggest that most of the inhabitants in the colonies refrain from livestock rearing. Respondents also indicates some reasons behind it; slum-owner`s prohibition and space shortage. Furthermore, both colonies possess small number of toilet facilities; 4 for Ranu's colony and 3 for Helal Miah`s colony, against 33 and 17 families, respectively. As for the former colony, three Muslim families consume 1 facility while the rest 30 families have to accommodate in the 3 facilities. Both colonies yield that slum owners dispose human wastes into drainage system adjacent to the facilities. Findings of this study also suggest that Malaria, Typhoid, Diarrhoea, Skin diseases appear common in both colonies. Among them, Diarrhoea has been observed to be the most frequent in two colonies. However, the findings also reveal the inhabitant`s perception toward the reasons behind such diseases.

\section{Conclusions}

This study resembled an attempt to find out the way slum dwellers of Sylhet city dispose their domestic wastes. This study also endeavoured to unfold the condition of the surrounding environment associated with the studied slums. To extract the current scenario, this study conducted a comparison between the studied slum areas (locally called colonies) namely; Ranu's colony and Helal Miah's colony. Findings unveiled that most of the respondents from both colonies disposes their home-grown wastes in the adjacent yards despite having particular places constructed by the municipality. Further, Most of the respondents acknowledged the municipality`s attempts to manage domestic wastes by van on a regular basis. However, the study found the differential perception among respondents in terms of waste management responsibility. Inhabitants of Ranu's colony favoured the slum-dwellers to bear up the responsibility, while dwellers of Helal Miah's colony held slum-owners responsible for waste management. Unfortunately, both slums encounters disproportionately constructed Toilet facilities. In order to alter their impoverished fate, Slum-dwellers involve themselves into multi-faceted income generating activities. Often, the concentrated slums make it difficult for the concerned authorities to precede their waste management conducts as per the plan that may hold potential risks for the surrounding environments. Therefore, it is recommended from this study that the local governments; city corporation or municipality, in conjunction with NGO's should devise an organised plan to make slum dwellers aware about potential risks associated with poorly disposed waste. Further study may include the interaction between poor waste management and its impact over the immediate environment.

\section{ACKNOWLEDGEMENT}

At first we would like to express our sincere gratitude to Almighty ALLAH, on whom we depend for sustenance, guidance and everything. We thank to our all participants who have made this research successful. We are really thankful to our friends; Sharmin Akther and Layla Nigar Akter for their help when it needed most. Lastly, we would also like to show our gratitude to Tasnim Labiba for her continuous non-materialistic support.

\section{REFERENCES}

[1] Abul, S. (2010). Environmental and Health Impact of Solid Waste Disposal at Mangwaneni Dumpsite In Manzini: Swaziland. Journal of Sustainable Development in Africa, 12(7), ISSN: 1520-5509.

[2] Babbie, E. (2004). The Practice of social Research ( $10^{\text {th }}$ ed.). Belmont, U.S.A.: Thomson Learning.

[3] Islam, M.N. (2008). An introduction to research method ( $2^{\text {nd }}$ ed). Dhaka, Bangladesh: Mullick \& Brothers.

[4] Islam, S.F.A., \& Islam, M. (2016). Case Study: An investigation on sanitation and waste management problem among the slum dwellers on Uttara, Dhaka. International Journal of Scientific Engineering and Applied Science (IJSEAS), 2 (1), ISSN: 2395-3470.

[5] Sankoh, F.P., Yan, X., \& Tran, Q. (2013). Environmental and Health Impact of Solid Waste Disposal in Developing Cities: A Case Study of Granville Brook Dumpsite, Freetown, Sierra Leone. Journal of Environmental Protection, 4, 665-670.

[6] Sylhet City Corporation (SCC) (2017). Retrieved from: http://scc.gov.bd/ 
[7] Tinni, S.H., Islam, M.A., Fatima, K., \& Ali, M.A. (2014). Impact of Tanneries Waste Disposal on Environment in Some Selected Areas of Dhaka City Corporation. J. Environ. Sci. \& Natural Resources, 7(1), $149-156$.

[8] United Nations Environment Program Agency (UNEPA) (2006). Informal Solid Waste Management. http://www.unep.org?PDF/Kenyawastemngntsector/sector/chapter1.pdf.

[9] Zurbrugg, C. (2002). Urban Solid Waste Management in Low-Income Countries of Asia: How to Cope with the Garbage Crisis. Presented for: Scientific Committee on Problems of the Environment (SCOPE) Urban Solid Waste Management Review Session, Durban, South Africa.

\section{AUTHORS' BIOGRAPHY}

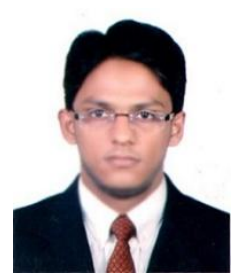

Mufti Nadimul Quamar Ahmed, He has completed his graduation in Sociology and currently pursuing his post graduation in the same discipline (With Thesis) at Shahjalal University of Science and Technology (SUST), Sylhet Bangladesh.

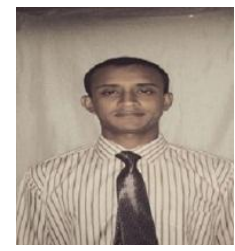

Golam Moula, He has completed his graduation in Sociology and currently pursuing his post graduation in the same discipline at Shahjalal University of Science and Technology (SUST), Sylhet Bangladesh.

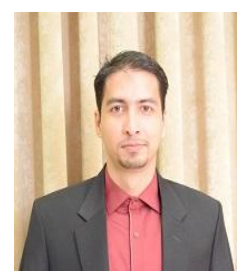

Sayed Bokth Mojumadar, He has completed his graduation in Sociology and currently pursuing his post graduation in the same discipline at Shahjalal University of Science and Technology (SUST), Sylhet, Bangladesh.

Citation: Mufti Nadimul Quamar Ahmed et al., "Scrutinizing Domestic Garbage Disposal Techniques of Slum Dwellers: A Study on Slum Areas of Sylhet City of Bangladesh". International Journal of Humanities Social Sciences and Education (IJHSSE), vol 4, no. 10, 2017, pp. 142-149. doi: http://dx.doi.org/10.20431/23490381.0410017.

Copyright: (C) 2017 Authors. This is an open-access article distributed under the terms of the Creative Commons Attribution License, which permits unrestricted use, distribution, and reproduction in any medium, provided the original author and source are credited. 